\title{
The Livestock Economy of Pakistan: An Agricultural Sector Model Approach
}

\author{
Muhammad A. Quddus, Stephen P. DAvies, and Donald W. LyBeCKeR
}

\begin{abstract}
The Pakistan Agricultural Sector Model (PASM) developed by Davies et al. (1991) was modified to enhance the livestock sub-sector. Nutrient-based rations replaced feedstuff-based rations and dry matter minimum and maximum constraints (stomach capacity) were added. Several initial simulations were undertaken to examine the structure of the modified model and its impact across the crop and livestock sub-sectors. These simulations included relaxing exogenous livestock numbers and selected crop hectarage constraints, and requiring that green forage be fed in the season grown. Most importantly, the results demonstrated that fodder hectarage will grow with livestock numbers to insure that sufficient green forage is available seasonally.

Two other analyses were performed to demonstrate the need to specify linkages between the crop and livestock sub-sectors. An analysis of transforming the livestock sub-sector from traditional to feedlot-based technology demonstrated that the reduced numbers of non-milking cattle needed for a given output of meat would provide the potential for increased production of various crops and other livestock products. Also, expanded cotton and Irri rice exports, hypothesised to occur through trade liberalisation from the Uruguay Round of the GATT, highlighted other inter-relationships between the crop and livestock sub-sectors. Greater production of both livestock and other crops might accompany the expansion of cotton production but less livestock feed would be available with expanded exports of Irri rice.
\end{abstract}

\section{INTRODUCTION}

Pakistan's livestock sub-sector has been largely neglected over the past 30 years. During the past three decades, that sub-sector has experienced an average growth rate of 2.9 percent per annum as compared to 4.0 percent for the crop subsector. However, population growth and improving living standards in Pakistan will increase the demand for livestock and livestock products in the future; under the existing production system it is unlikely that this demand will be met. According to the National Commission on Agriculture [Government of Pakistan (1988)], if the present strategy continues, the demand will soon be far greater than domestic supply for agricultural products, especially for livestock products. The National Commission on Agriculture predicted that, during the year 2000, Pakistan will need

Muhammad A. Quddus is Agricultural Economist with Pakistan Agricultural Research Council. Stephen P. Davies is Associate Professor and Donald W. Lybecker is Professor in the Department of Agricultural and Resource Economics, Colorado State University, Fort Collins, Colorado, USA. 
to import 1.08 million metric tons of meat and 1.86 million metric tons of milk to meet the expected demand. If these projections are correct, Pakistan will have to spend substantial foreign exchange for imports of livestock and livestock products. An alternative to increased imports would be to increase the productivity of the livestock sector. However, the Report of Prime Minister's Task Force on Agriculture [Government of Pakistan (1993)] suggests that the livestock sector is not a primal concern.

Careful policy analysis and development planning are required to identify appropriate measures to enhance the livestock sub-sector. An important and appropriate tool in this process is the linear programming sector model because it considers the livestock sub-sector in the context of the wider agricultural economy. A notable strength of the sector model is that it explicitly recognises interdependencies of various sub-sectors. Thus, policy or technology changes designed to enhance the livestock sub-sector will be reflected in changes in the crop sub-sector. Likewise, changes in the cropping pattern will have impacts on the livestock sub-sector.

Few, if any, studies have taken this linkage into specific account for Pakistan. A review of the 1990-1995 issues of The Pakistan Development Review showed articles focusing on issues of livestock [Akmal (1993, 1994)] and crops and irrigation [Ali (1990); Rosegrant and Evenson (1993) and Ahmad and Sampath (1994)], but no articles considered interactions between the livestock and crop subsectors. Faruqee and Carey (1995) examine the role of government in the aggregate agricultural sector and assess issues relevant to both crops and livestock, but they do not model nor highlight these inter-relationships. Therefore, the purpose of this paper is to use a linear programming sector model to examine the crop and livestock linkages in the agricultural sector of Pakistan.

The paper briefly reviews the linear programming sector analysis literature, and describes the Pakistan Agricultural Sector Model (PASM) [Davies et al. (1991)] in general terms. It then contrasts the feedstuff-based livestock component in the original PASM with a nutrient-based livestock component (Model 1) developed by Quddus (1993), and uses the latter specification to show implications of several livestock component enhancements. The livestock component enhancements include adding stomach capacity limitations, relaxing the specified level of kharif fodder production, requiring green forage to be fed in the season in which it is produced, and allowing livestock numbers to be determined endogenously.

\section{METHODOLOGY}

Agricultural sector models typically include the production and disposition of all major crop and animal products in a country. The usual purpose of such a model is to determine how the agricultural sector would react to possible policy or technological changes. 
Agricultural policy analysts have long used price endogenous sector models. Samuelson (1952) showed that the maximisation of a single function (the sum of producer and consumer surpluses) induces the model to replicate a competitive equilibrium in a single product market. Takayama and Judge (1964, 1964a) extended Samuelson's concept to trade between spatially separated markets. Duloy and Norton (1973, 1975) used mathematical programming models to simulate behaviour of a complete agricultural sector. They advocated the use of the grid linearisation technique to avoid the difficulties of solving quadratic programmes.

Applications of sector modelling for policy analysis are numerous. Hazell and Norton (1986) discussed different ways of using existing sector models for Mexico, Turkey, and Egypt, and more recently, Apland and Andersson (1996) have developed a limited sector model for Sweden. This Swedish application examined the optimal plant location of dairy processing firms in a multi-region model that had some sectoral dimensions. Other analyses using variations of agricultural sector models include a diverse set of topics. The Agricultural Sector Model of the US has been used to evaluate farm programme changes, the impact of bio-technology, and the effects of pollution control and global warming [Adams, Hamilton and McCarl (1986); Chang et al. (1992) and Coble et al. (1992)].

\section{PAKISTAN AGRICULTURAL SECTOR MODEL}

The Pakistan Agricultural Sector Model (PASM) was developed by Colorado State University and AGRI-BI-CON economists, and refined in the Economic Wing of the Ministry of Agriculture [Davies et al. (1991)]. It was designed to combine the production and demand for 11 crop and 6 livestock products in the context of resources available to farms of different sizes (and technologies) and different zones. In addition, it can: (1) account for losses, costs, and capacity constraints in marketing and processing farm products; (2) incorporate supply response curves for inputs used in production; and (3) specify the crop sub-sector to provide inputs to the livestock sub-sector.

The PASM objective function calculates the value of consumer and producer surpluses from producing, marketing, and importing/exporting of major crops and livestock in Pakistan. The assumption for all commodities except basmati rice is that export and import markets are perfectly elastic, i.e., the small-country case is assumed. Basmati rice has a downward sloping demand curve for its exports. Resources are restricted either by farm size or by geographical zone or region. Water and fertiliser, for example, can be used by different farm types in each zone, but not by farm activities in other zones.

Six livestock production activities in the model require crop inputs as feed and provide their by-products to various cropping activities and final outputs of the model. Livestock production activities are defined on a zonal basis and produce a commodity together with nitrogen via manure, and they require feedstuffs from the 
crop sub-sector. Cattle and buffaloes are combined into milking and non-milking categories. The former provides only milk while the latter's output is meat. Goats and sheep, which produce only mutton, are in a third category. Finally, there are three poultry activities: broilers which produce meat; layers which produce eggs and meat; and desi chickens which produce eggs and meat.

The PASM was developed as a policy analysis tool, originally to understand the importance of agribusiness development in Pakistan, and later as a method of summarising many of the continuing activities and policy exercises in the Economic Wing of the Ministry of Agriculture [Davies et al. (1991)]. The Economic Wing regularly updates the main types of data required for PASM: general statistics for the food and fibre sector; farm budgets by cropping zone; marketing margin analyses for the main commodities; and estimates of producer and consumer subsidy equivalents, which require a calculation of border prices and other policy costs of the main crops in Pakistan. Thus the PASM was constructed from these categories of data to make policy analysis more effective and systematic. Also, it was intended to act as a unifying model, helping analysts in each area of the Economic Wing check the consistency of data and assumptions against each other.

\section{THE LIVESTOCK SECTOR MODEL: AN ADAPTATION OF PASM}

Important changes in the livestock sub-sector of the PASM are the focus of this paper. The modifications were designed to incorporate flexibility into the livestock sub-sector not provided for originally. Tables 1 and 2 provide schematics of the principal differences of the two models. The crop sub-sector and PASM's processing and pricing components have been retained unchanged.

Table 1 reflects the livestock feeding structure of PASM in columns 2 through 7 and rows A through D. These columns contain four crop (cols. 2-5) and two livestock production (cols. 6-7) activities, while rows A through D show four feedstuffs being produced and then utilised by the two livestock activities. These supply-demand balance rows have negative coefficients for supplies of feedstuffs, while the livestock activities have positive coefficients and reflect the demand for feedstuffs. Each crop production activity brings in specific amounts of the four feedstuffs in rows A through D, so that one hectare of basmati rice production provides, in addition to clean rice, 200 kilograms of bran and grain, 2,544 kilograms of straw and 34 kilograms of green fodder. If the model chooses other crop activities (cols. 3-5), then different proportions of the same four feedstuffs are produced.

The four feedstuffs are combined into rations in columns 6 and 7. Annually, each standardised non-milking cow unit needs 21 kilograms of bran and grain, 820 kilograms of straw, 556 kilograms of green fodder in kharif and 1,670 kilograms in rabi. In this manner, constraints on the cropping pattern arise through the necessity 
Table 1

Feedstuff and Livestock Structure of Original PASM

\begin{tabular}{|c|c|c|c|c|c|c|c|c|c|c|}
\hline & $\begin{array}{c}\text { Columns/Rows } \\
\text { (1) }\end{array}$ & $\begin{array}{c}\text { Grow } \\
\text { Basmati } \\
\text { Rice } \\
(1 \mathrm{Ha}) \\
(2)\end{array}$ & $\begin{array}{c}\text { Grow } \\
\text { Wheat } \\
(1 \mathrm{Ha}) \\
(3)\end{array}$ & $\begin{array}{c}\text { Grow } \\
\text { Kharif } \\
\text { Forage } \\
(1 \mathrm{Ha}) \\
(4)\end{array}$ & $\begin{array}{c}\text { Grow } \\
\text { Rabi } \\
\text { Forage } \\
(1 \mathrm{Ha}) \\
(5)\end{array}$ & $\begin{array}{c}\text { Non- } \\
\text { milking } \\
\text { Cows } \\
(1 \mathrm{Hd}) \\
(6)\end{array}$ & $\begin{array}{c}\text { Milking } \\
\text { Cows } \\
(1 \mathrm{Hd}) \\
(7) \\
\end{array}$ & $\begin{array}{c}\text { Process/ } \\
\text { Market } \\
\text { Beef } \\
(1 \mathrm{Kg} .) \\
(8) \\
\end{array}$ & $\begin{array}{c}\text { Process/ } \\
\text { Market } \\
\text { Milk } \\
(1 \mathrm{Kg} .) \\
(9) \\
\end{array}$ & $\begin{array}{l}\text { RHS } \\
(10) \\
\end{array}$ \\
\hline (A) & Bran \& Grain (Kg.) & -200 & -439 & & & 21 & 276 & & & $<=0$ \\
\hline (B) & Straw (Kg.) & -2544 & -2336 & & & 820 & 820 & & & $<=0$ \\
\hline \multirow[t]{2}{*}{ (C) } & Green Fodder & & & & & & & & & \\
\hline & Kharif (Kg.) & -34 & & -11277 & & 556 & 556 & & & $<=0$ \\
\hline \multirow[t]{2}{*}{ (D) } & Green Fodder & & & & & & & & & \\
\hline & Rabi (Kg.) & & -94 & & -27873 & 1670 & 1670 & & & $<=0$ \\
\hline \multirow[t]{2}{*}{ (E) } & Non-milking & & & & & & & & & \\
\hline & Cows (Hd) & & & & & 1 & & & & $=1000$ \\
\hline \multirow[t]{2}{*}{ (F) } & Milking & & & & & & & & & \\
\hline & Cows (Hd) & & & & & & 1 & & & $=1000$ \\
\hline (G) & Beef (Kg.) & & & & & -167 & & 1 & & $<=0$ \\
\hline (H) & Milk (Kg.) & & & & & & -1075 & & 1 & $<=0$ \\
\hline
\end{tabular}


Table 2

Feedstuffs and Livestock Structure of the Nutrient-based Model (Model 1)

\begin{tabular}{|c|c|c|c|c|c|c|c|c|c|}
\hline & $\begin{array}{c}\text { Columns/Rows } \\
\text { (1) } \\
\end{array}$ & $\begin{array}{c}\text { Grow } \\
\text { Basmati } \\
\text { Rice (1 Ha) } \\
(2) \\
\end{array}$ & $\begin{array}{l}\text { Grow } \\
\text { Kharif } \\
\text { Forage } \\
(1 \mathrm{Ha}) \\
(3)\end{array}$ & $\begin{array}{c}\text { Non- } \\
\text { Milking } \\
\text { Cow (1 Hd) } \\
(4)\end{array}$ & $\begin{array}{c}\text { Convert } \\
\text { Concentrate } \\
(100 \mathrm{Kg} .) \\
(5) \\
\end{array}$ & $\begin{array}{c}\text { Convert } \\
\text { Straw } \\
(100 \mathrm{Kg} .) \\
(6) \\
\end{array}$ & $\begin{array}{c}\text { Convert } \\
\text { Kharif } \\
\text { Fodder } \\
(100 \mathrm{Kg} .) \\
(7) \\
\end{array}$ & $\begin{array}{c}\text { Process/ } \\
\text { Market Beef } \\
(1 \mathrm{Kg} .) \\
(8) \\
\end{array}$ & $\begin{array}{c}\text { RHS } \\
(9) \\
\end{array}$ \\
\hline (A) & Concentrate(Kg.) & -200 & & & 100 & & & & $<=0$ \\
\hline (B) & Straw (Kg.) & 2544 & & & & 100 & & & $<=0$ \\
\hline (C) & Fodder (Kg.) & -34 & -11277 & & & & 100 & & $<=0$ \\
\hline (D) & TCP (Kg.) & & & 190 & -11 & -4 & -7 & & $<=0$ \\
\hline (E) & DE (Mcal) & & & 5402 & -267 & -304 & -181 & & $<=0$ \\
\hline$(\mathrm{F})$ & Beaf (Kg.) & & & -167 & & & & 1 & $<=0$ \\
\hline \multirow[t]{2}{*}{ (G) } & Roughage & & & & & & & & \\
\hline & Max. (Kg.) & & & -2245 & & 100 & 100 & & $<=0$ \\
\hline \multirow[t]{2}{*}{$(\mathrm{H})$} & Roughage & & & & & & & & \\
\hline & Min. (Kg.) & & & 1309 & & -100 & -100 & & $<=0$ \\
\hline \multirow[t]{2}{*}{ (I) } & Non-milking & & & & & & & & \\
\hline & Cows (Hd) & & & 1 & & & & & $=1000$ \\
\hline
\end{tabular}


of providing feedstuffs. The PASM contains several rations for each type of livestock, so there are alternative feeding regimes available.

The remaining columns represent the two livestock processing and marketing activities (cols. 8-9). Rows $\mathrm{E}$ and $\mathrm{F}$ require that 1,000 head each of non-milking cows and milking cows be maintained. These equality constraints imply that animals must be fed before other demands are met. Thus, PASM's livestock component importantly affects the rest of the model. Rows $\mathrm{G}$ and $\mathrm{H}$ transfer the livestock products, beef and milk, from production activities (negative coefficients) to processing and marketing activities (positive coefficients).

Table 2 shows the structure of the revised livestock sub-sector developed by Quddus (1993), hereafter Model 1. Columns 2 and 3 are crop production activities with by-products allocated to concentrate, straw, and/or fodder feedstuff classes (rows A-C). The feedstuff classes are converted (at no cost) to Total Crude Protein (TCP) and Digestible Energy (DE) equivalents in columns 5 through 7. These feedstuff classes represent different TCP/DE ratios; all grain, by-products, forages, and other feedstuffs are placed in varying proportions into one or more of the classes. Non-milking cow requirements for TCP and DE are shown in column 4 (rows D and $\mathrm{E}$ ), and are met by the provision of TCP and DE. The production of beef is transferred from non-milking cows (col. 4) to processing and marketing of beef (col. 8) in row $F$.

Minimum and maximum restrictions on roughage intake are shown in rows $G$ and $\mathrm{H}$. In row $\mathrm{G}$, the amount of dry matter fed (positive coefficients) cannot exceed the level stated for the livestock activity in column 4 (negative coefficient) because the equation has a $<=$ constraints. The coefficient signs are reversed for the minimum roughage constraint shown in row H. Row I, which requires that a fixed number of non-milking cows be fed, is the constraint that drives the whole feeding system. These limitations are added in Model 3 to show their impact on cropping patterns and livestock feeding regimes, but they are not included in Model 1.

The Model 1 structure permits greater flexibility in meeting the nutritional requirements of livestock and reduces the rigidity between crops produced and rations fed as compared to the original PASM, which requires that fixed combinations of feedstuffs be provided for each ration. Thus in PASM, crops like cotton or oilseeds must be produced to a level that yields sufficient concentrate for each ration, which can be a determining factor in the production level of a given crop. In Model 1, levels of protein and energy required for a given ration can be met through several combinations of crops using various roughages and different sources of concentrates.

The Model 1 livestock and poultry rations have a nutrient design based on energy and protein units. All livestock and poultry are defined in terms of standard animal units, $410 \mathrm{kgs}$. for livestock and 750 grams for poultry [National Academy of Sciences (1977, 1978, 1984, 1985)]. For livestock (dairy cattle, beef cattle, sheep, 
and goats), the nutrient requirements are defined in terms of TCP and DE. All poultry (broilers, layers, and desi) activities have nutrient requirements defined in terms of TCP and Metabolisable Energy (ME). Ration 1 is a base ration and reflects typical feeding and production levels in Pakistan. The other livestock rations represent increasing production (output) levels with appropriate protein and energy inputs. The poultry rations all have the same output but use different proportions of TCP and DE, expect for Ration 3, which has a higher production of meat and eggs and uses more of both TCP and DE.

The validation of Model 1 was undertaken by comparing its solution with 1987-88 crop hectarage, and livestock and poultry numbers at the national and provincial levels. As shown in Tables 3 and 4, most key comparisons between the

Table 3

Comparison of Crop Hectarage Levels of Model 1 Versus Actual 1987-88 and the PASM (1000 Hectares)

\begin{tabular}{lrrr}
\hline Crops & Actual & & \\
\hline Kharif & $1987-88$ & PASM & Model 1 \\
Basmati Rice & & & \\
Irri rice & 916 & 953 & 1,007 \\
Coarse Grains & 1,128 & 1,203 & 1,144 \\
Cotton & 1,740 & 1,477 & 1,330 \\
Sugarcane & 2,568 & 2,486 & 2,571 \\
Trad. Oilseed & 842 & 722 & 674 \\
N. T. Oilseed & 157 & 160 & 70 \\
Pulses & 7 & 7 & 7 \\
Vegetables & 216 & 215 & 215 \\
Fodder & 220 & 245 & 218 \\
Total Hectares & 1,089 & 1,089 & 1,089 \\
Rabi & 8,883 & 8,557 & 8,324 \\
Wheat & & & \\
Barley & 7,725 & 7,560 & 7,675 \\
Pulses & 153 & 0 & 0 \\
Vegetables & 1,052 & 1,519 & 1,465 \\
Trad. Oilseed & 191 & 0 & 0 \\
N. T. Oilseed & 279 & 280 & 280 \\
Fodder & 22 & 22 & 22 \\
Fruit & 1,294 & 1,195 & 542 \\
Total Hectares & 416 & 391 & 475 \\
\hline & 11,132 & 10,967 & 10,459 \\
\hline
\end{tabular}


Table 4

Actual 1987-88 Livestock Numbers and Livestock Numbers for Alternative Rations in the PASM and Model 1 (1000 Head)

\begin{tabular}{|c|c|c|c|}
\hline Livestock Category & $\begin{array}{c}\text { Actual } \\
1987-88\end{array}$ & PASM & Model 1 \\
\hline \multicolumn{4}{|l|}{ Milking Cows } \\
\hline Ration $1^{\text {a }}$ & & 4,032 & 0 \\
\hline Ration 2 & & 4,577 & 313 \\
\hline Ration 3 & & 3,392 & 10,905 \\
\hline Total M Cows & 12,001 & 12,001 & 11,218 \\
\hline \multicolumn{4}{|l|}{ Non-milking Cows } \\
\hline Ration 1 & & 18,436 & 18,160 \\
\hline Ration 2 & & 1,227 & 0 \\
\hline Ration 3 & & 0 & 0 \\
\hline Total NM Cows & 19,663 & 19,663 & 18,160 \\
\hline \multicolumn{4}{|l|}{ Sheep and Goats } \\
\hline Ration 1 & & 0 & 0 \\
\hline Ration 2 & & 0 & 4,889 \\
\hline Ration 3 & & 5,765 & 712 \\
\hline Total S \& G & 5,765 & 5,765 & 5,601 \\
\hline \multicolumn{4}{|l|}{ Poultry_Broilers } \\
\hline Ration 1 & & 38,420 & 189 \\
\hline Ration 2 & & 0 & 1,691 \\
\hline Ration 3 & & 4,110 & 33,770 \\
\hline Ration 4 & & 23,040 & 30,143 \\
\hline Total Broilers & 70,090 & 65,570 & 65,792 \\
\hline \multicolumn{4}{|l|}{ Poultry_Layers } \\
\hline Ration 1 & & 0 & 1,438 \\
\hline Ration 2 & & 0 & 0 \\
\hline Ration 3 & & 15,700 & 11,260 \\
\hline Ration 4 & & 7,680 & 10,091 \\
\hline Total Layers & 23,380 & 23,380 & 22,789 \\
\hline Poultry_Desi & 56,940 & 56,940 & 55,763 \\
\hline
\end{tabular}

${ }^{\mathrm{a}}$ Livestock rations are listed from least productive (Ration 1) to most productive (Ration 3). Poultry rations all have the same productivity but use different combinations of TCP and DE, except for Ration 3, which has a higher output of meat and eggs, but also uses more TCP and DE. 
Model 1 solution and the 1987-88 national levels indicated similarities. The Model 1 solution was also comparable to the PASM results. The general criterion used in these exercises is that values within five percent of actual levels are considered to be very good and those within ten percent are considered adequate [Hazell and Norton (1986)].

Model 1 hectarages for most major crops (basmati rice, Irri rice, cotton, wheat, and vegetables) are consistent with 1987-88 levels. Oilseeds, pulses, and fodder have identical values with 1987-88 because their hectarages are restricted not to exceed observed areas. The traditional oilseeds in kharif also were restricted to levels seen in 1987-88, but the solution in Model 1 does not find it profitable enough to utilise even the hectarage allowed. The coarse grain and sugarcane simulations are somewhat low as compared to the 1987-88 reported area, and total kharif cropped area is about six percent below that reported. The land in rabi pulses is about 40 percent above the 1987-88 levels, whereas fodder production is less than half.

Relative to the PASM model, Model 1 compared favourably. PASM was more accurate for basmati rice, coarse grains, sugarcane, and rabi fodder among the major crops. Model 1 was closer to the 1987-88 hectarages for Irri rice and wheat, and after several adjustments described in the following section, both kharif and rabi fodder perform better in the study models than in the PASM.

Table 4 shows the number of animal units maintained on various rations for Model 1 and the PASM, along with the 1987-88 units of milking cows, non-milking cows, sheep and goats, broilers, layers, and desi poultry. With the exception of broilers, the PASM exogenously specified the livestock/poultry numbers at the actual levels and forced the cropping sector to respond to this rigidity. The lower broiler level was necessary to render a feasible solution. In Model 1, the reported livestock numbers are set at the maximum values that supported a feasible solution, but they are still quite close to the levels for 1987-88.

The added flexibility of Model 1 allows more animals to be fed higher performance rations for milking cows, sheep and goats, and broilers. (However, some of the improvement is due to the lower livestock numbers in Model 1.) The variation of rations used remains about the same in both the PASM and Model 1 for non-milking cows and layers. As no systematic data on rations by type of livestock exists, the simulations reported here are a useful way to examine impacts of policy and food system changes on the livestock sub-sector. When most animals are fed a high performance ration, an implication is that a modern feeding or milking system is in place. Lower performance rations infer a traditional setting.

To improve the accuracy of Model 1, several modifications in forage availability and livestock roughage requirements were tried. These are reported in the next section. 


\section{EMPIRICAL ANALYSIS AND RESULTS}

Seven additional models were developed to show sequentially the changes in Model 1, the initial study model. The restrictions imposed or relaxed in the associated models are:

(a) Model 2 drops hectarage restrictions on kharif fodder, kharif pulses, and all oilseeds from Model 1.

(b) Model 3 adds roughage constraints to Model 1 which require a minimum and maximum level of dry matter by livestock class.

(c) Model 4 relaxes the kharif fodder hectarage limitations from Model 3 to permit the optimum level to enter rather than the hectarages reported during 1987-88.

(d) Model 5 takes the structure of Model 4 and restricts the feeding of kharif and rabi fodder and other green forage to their production seasons.

(e) Model 6 modifies Model 5 to make the livestock and poultry restrictions to be equal to or less than the 1987-88 levels rather than as equalities.

(f) Model 7 modifies Model 5 by expanding Irri rice exports by 33 percent in the context of maintaining the 1987-88 livestock and poultry numbers.

(g) Model 8 modifies Model 5 by expanding the raise in the price of cotton exports by 25 percent in the context of maintaining the 1987-88 livestock and poultry numbers.

Table 5 presents changes in cropped hectarage for the seven scenarios above, while livestock numbers maintained on each ration for each scenario are found in Table 6. The first comparison of interest is between Model 2 and the actual values for 1987-88. Model 2 does not impose Model 1's hectarage limits on fodder, pulses or oilseeds, and its results are quite good for both types of rice, cotton, and vegetables in kharif, and fruit in rabi season. While sugarcane and barley hectarages differ from the actual by significant percentages, their total hectarage is not especially divergent. A number of commodities in Model 2 had hectarages that are quite different from actual levels: fodder, oilseeds, and pulses in both seasons, coarse grains, and wheat. Most of these crops are tied to livestock as fodder is used as green forage, coarse grains are predominately used for livestock feed, and oilseeds provide cake for livestock rations. The divergence of wheat hectarage is mainly driven by changes in the aforementioned crops.

One reason for these differences is that linear programming sector models have a tendency towards excessive specialisation, and over-exploit efficiencies of production technologies because the model does not reflect all biological restrictions. A prime example is pulses. In Model 2, the hectarage of pulses during kharif is far greater than actual, but none is grown in rabi. This crop is modelled as an aggregation of the four main pulses produced in Pakistan-mung, mash, gram, and masoor - and only the first two are grown in kharif. Gram is the main pulse, with 
Table 5

Comparison of Crop Hectarage Levels of the Models 2 through 8 Versus the Actual 1987-88 (1,000 Hectares)

\begin{tabular}{|c|c|c|c|c|c|c|c|c|}
\hline Crops & $\begin{array}{c}\text { Actual } \\
1987-88\end{array}$ & Model 2 & Model 3 & Model 4 & Model 5 & Model 6 & Model 7 & Model 8 \\
\hline \multicolumn{9}{|l|}{ Kharif } \\
\hline Basmati Rice & 916 & 996 & 991 & 1,038 & 987 & 1,012 & 985 & 986 \\
\hline Irri Rice & 1,128 & 1,123 & 1,174 & 1,162 & 1,179 & 1,219 & 1,357 & 1,185 \\
\hline Coarse Grains & 1,740 & 960 & 1,108 & 1,181 & 1,221 & 1,427 & 1,266 & 854 \\
\hline Cotton & 2,568 & 2,343 & 2,610 & 2,938 & 2,730 & 2,825 & 2,525 & 3,079 \\
\hline Sugarcane & 842 & 666 & 702 & 748 & 760 & 707 & 759 & 757 \\
\hline Trad. Oilseed & 157 & 878 & 160 & 160 & 160 & 160 & 160 & 160 \\
\hline N. T. Oilseed & 7 & 1,219 & 7 & 7 & 7 & 7 & 7 & 7 \\
\hline Pulses & 216 & 218 & 215 & 215 & 215 & 215 & 215 & 215 \\
\hline Vegetables & 220 & 154 & 190 & 194 & 226 & 226 & 226 & 226 \\
\hline Fodder & 1,089 & 0 & 1,089 & 372 & 871 & 414 & 892 & 834 \\
\hline Total & 8,883 & 8,852 & 8,246 & 8,015 & 8,356 & 8,212 & 8,392 & 8,303 \\
\hline \multicolumn{9}{|l|}{ Rabi } \\
\hline Wheat & 7,724 & 6,598 & 7,151 & 6,982 & 7,128 & 7,513 & 7,092 & 6,989 \\
\hline Barley & 153 & 216 & 0 & 0 & 246 & 0 & 254 & 479 \\
\hline Pulses & 1,052 & 0 & 1,344 & 1,177 & 1,538 & 1,547 & 1,605 & 1,212 \\
\hline Vegetables & 191 & 0 & 81 & 80 & 0 & 0 & 0 & 0 \\
\hline Trad. Oilseed & 279 & 1,371 & 280 & 280 & 280 & 280 & 280 & 280 \\
\hline N. T. Oilseed & 22 & 64 & 22 & 22 & 22 & 22 & 22 & 22 \\
\hline Fodder & 1,294 & 1,739 & 1,628 & 1,901 & 1,377 & 966 & 1,346 & 1,405 \\
\hline Fruit & 416 & 443 & 451 & 456 & 416 & 429 & 407 & 402 \\
\hline Total & 11,131 & 10,431 & 10,957 & 10,898 & 11,007 & 10,757 & 11,006 & 11,009 \\
\hline
\end{tabular}


Table 6

Livestock Maintained on Alternative Rations Models 2 through 8 Versus the Actual Livestock in 1987-88 (1000 Head)

\begin{tabular}{|c|c|c|c|c|c|c|c|c|}
\hline Category $^{\mathrm{a}}$ & $\begin{array}{c}\text { Actual } \\
1987-88\end{array}$ & Model 2 & Model 3 & Model 4 & Model 5 & Model 6 & Model 7 & Model 8 \\
\hline \multicolumn{9}{|l|}{ Milking Cows } \\
\hline Ration 1 & & 3,953 & 7,508 & 7,695 & 6,800 & 946 & 6,833 & 6,697 \\
\hline Ration 2 & & 313 & 318 & 0 & 337 & 5,675 & 347 & 204 \\
\hline Ration 3 & & 6,952 & 3,392 & 3,523 & 4,081 & 4,597 & 4,038 & 4,317 \\
\hline Total M Cows & 12,001 & 11,218 & 11,218 & 11,218 & 11,218 & 11,218 & 11,218 & 11,218 \\
\hline \multicolumn{9}{|l|}{ Non-milking Cows } \\
\hline Ration 1 & & 16,834 & 17,675 & 17,913 & 18,145 & 8,658 & 18,160 & 18,122 \\
\hline Ration 2 & & 0 & 0 & 0 & 0 & 427 & 0 & 0 \\
\hline Ration 3 & & 1,326 & 485 & 247 & 15 & 0 & 0 & 38 \\
\hline Total NM Cows & 19,663 & 18,160 & 18,160 & 18,160 & 18,160 & 9,085 & 18,160 & 18,160 \\
\hline \multicolumn{9}{|l|}{ Sheep and Goats } \\
\hline Ration 1 & & 4,149 & 5,601 & 5,601 & 4,926 & 0 & 5,004 & 4,943 \\
\hline Ration 2 & & 1,452 & 0 & 0 & 675 & 5,384 & 597 & 658 \\
\hline Ration 3 & & 0 & 0 & 0 & 0 & 217 & 0 & 0 \\
\hline Total S \& G & 5,765 & 5,601 & 5,601 & 5,601 & 5,601 & 5,601 & 5,601 & 5,601 \\
\hline
\end{tabular}




\begin{tabular}{|c|c|c|c|c|c|c|c|c|}
\hline Category $^{\mathrm{a}}$ & $\begin{array}{c}\text { Actual } \\
1987-88\end{array}$ & Model 2 & Model 3 & Model 4 & Model 5 & Model 6 & Model 7 & Model 8 \\
\hline \multicolumn{9}{|l|}{ Poultry-Broiler } \\
\hline Ration 1 & & 43,963 & 36,708 & 37,885 & 0 & 0 & 0 & 0 \\
\hline Ration 2 & & 2,042 & 0 & 0 & 0 & 0 & 0 & 0 \\
\hline Ration 3 & & 17,465 & 13,290 & 12,116 & 65,792 & 65,792 & 65,792 & 65,792 \\
\hline Ration 4 & & 2,321 & 15,794 & 15,791 & 0 & 0 & 0 & 0 \\
\hline Total Broilers & 70,090 & 65,792 & 65,792 & 65,792 & 65,792 & 65,792 & 65,792 & 65,792 \\
\hline \multicolumn{9}{|l|}{ Poultry-Layer } \\
\hline Ration 1 & & 5,800 & 17,388 & 15,285 & 0 & 0 & 0 & 0 \\
\hline Ration 2 & & 0 & 0 & 0 & 0 & 0 & 0 & 0 \\
\hline Ration 3 & & 16,989 & 5,401 & 7,504 & 22,789 & 22,789 & 22,789 & 22,789 \\
\hline Ration 4 & & 0 & 0 & 0 & 0 & 0 & 0 & 0 \\
\hline Total Layers & 23,380 & 22,789 & 22,789 & 22,789 & 22,789 & 22,789 & 22,789 & 22,789 \\
\hline Poultry_Desi & 56,940 & 55,763 & 55,763 & 55,763 & 55,763 & 55,763 & 55,763 & 55,763 \\
\hline
\end{tabular}

${ }^{\mathrm{a}}$ Livestock rations are listed from least productive (Ration 1) to most productive (Ration 3). Poultry rations all have the same productivity but use different combinations of TCP and DE, except for Ration 3, which has a higher output of meat and eggs, but also uses more TCP and DE. 
over one million hectares of production, and it is only grown in rabi. The model, however, uses higher-yielding kharif varieties to produce the full complement of pulses. To account for these biological limitations, the hectarage of kharif pulses in Models 3 through 8 is restricted to be no greater than its actual 1987-88 level.

Another reason for the low hectarage of sugarcane, coarse grains, and kharif fodder is that two joint products are produced from oilseeds, cake, and oil. In Model 2 , when land restrictions are lifted, oilseed production increases dramatically to reduce edible oil imports and raise oilseed cake supply for livestock rations. Therefore, the land in forage declines and other crops can be produced. With adequate feedstuffs provided through oilseed production, the coarse grain hectarage is reduced substantially. Cotton also provides cake and oil along with fibre, and so its hectarage might be expected to expand as well. However, its yield of oil is low relative to other oilseeds, so it does not react in the same manner. Oilseed levels in Model 2 may exceed actual areas because of the lack of a currently viable marketing system to handle the increased oilseed production. Additional processing capacity is needed and local marketing channels require development if that industry is to grow as indicated in Model 2.

The subsequent models are cumulative in that they usually use the immediately preceding model as their starting-point. Models 3 and 4 show the impacts of adding ration roughage limits. Model 3 takes the structure of Model 1 as its base and adds maximum and minimum limits on roughage intake for non-milking cows, milking cows, and sheep and goats. Kharif fodder is still forced into Model 3 at the Model 1 level. Model 4 has the same roughage constraints but does not force kharif fodder hectarage into the solution. Relative to Model 2, which has no hectarage constraints, fodder production increases in Model 4; yet the simulated hectarage is still only one-third of actual fodder levels in kharif. Thus, roughage limits only partially explain the high fodder hectarage in the agricultural sector of Pakistan.

In Model 5, a more realistic seasonality constraint was imposed to limit the use of green fodder to its growing season. Fodder hectarage climbs by 500 thousand hectares and the levels for sugarcane, rabi fodder, and barley also improve. Model 5 therefore demonstrates the importance to cropping patterns of the seasonality constraints in livestock feeding. By implication, provision of higher oilseed output or other sources of feedstuffs might reduce the need for land in fodder because the availability of feedstuffs is more important than roughage/concentrate combinations.

Table 6 shows that changes also occurred in rations. Overall, there is better quality feeding in Model 5 as compared to Model 4, with the exception of nonmilking cows. (Higher numbered rations have higher output in the livestock categories. The poultry rations all have the same output except for Ration 3, which has higher production of meat and eggs and also uses more TCP and DE. See the Notes to Table 6.) This demonstrates that a model with both roughage restrictions 
and seasonality constraints results in more realistic area in production, with fewer restrictions, and allows for more diverse and probably appropriate livestock feeding regimes.

In Model 6, the equality restrictions on livestock numbers used in the previous models are set to be equal or less than constraints, so the model chooses both the herd size as well as their rations. This simulation represents a simple proxy for a transition from a traditional to a modern, feedlot-based livestock sub-sector. Given the multiple purposes that livestock provide to small farms in a traditional system, (transport, bullock labour, store of wealth, etc.), it is plausible that the numbers of livestock would fall as the industry modernises. The greatest change in Model 6 is in the non-milking cow numbers, which drop by about half (Table 6). With fewer nonmilking cows to maintain, all other livestock categories are given improved rations and land is released from fodder for other purposes. The differences between Models 5 and 6 also demonstrate some important features about the role of demand, and how roughage and seasonality constraints affect various crops.

The hectarages of basmati rice, Irri rice, and wheat increase in Model 6 when extra land is available, suggesting that these crops are limited by livestock feed requirements. This is confirmed by the retail demand figures that show rising domestic consumption of these crops in Model 6. In contrast, the consumption of cotton fibre, sugar, pulses, and vegetables does not change despite the increased availability of land and other resources. For Irri rice and cotton fibre, these results are consistent with those of Davies (1996), who showed a considerable export response for Irri rice when prices and export limits are raised, but far less so for cotton fibre. The higher energy rations in Model 6 lead to added consumption of milk and mutton, by 9 percent and 16 percent respectively, while poultry products do not change and beef consumption declines by 17 percent with the reduced herd size.

The general responsiveness of crops to alternative assumptions in Models 5 and 6 is seen by reviewing the restrictions that are binding and how various crops provide roughage and concentrate. Excess roughage from straw from crops produced for food is usually sufficient when not constrained by season, and most crops provide at least some Digestible Energy (DE) and Total Crude Protein (TCP) from straw. Basmati rice, wheat, and sugarcane provide the greatest amounts per hectare among food crops, but they are constrained by limits on demand and livestock stomach capacity. Green fodder and concentrate are therefore required, which is made apparent by the fact that the maximum roughage constraint, the provision of concentrate, and the availability of seasonal roughage are typically binding restrictions. Minimum stomach capacities are never binding, so more concentrate could be fed. The most variable crops are those providing seasonal roughage or concentrate. Rabi fodder, kharif fodder, and sugarcane contribute by far the greatest DE and TCP per hectare, with other crops providing at most one-tenth of these crops. Sugarcane faces limited demand and also uses hectarage in both seasons, so it has a 
high opportunity cost in terms of its land usage. In Model 6, with less livestock to feed, the land put into these three crops is reduced substantially and other crops are added. Oilseed cake provides the greatest concentrate per hectare, but its availability is limited by hectarage restrictions on traditional and non-traditional oilseeds, and by export limits on cotton. Thus, fodder effectively supplies both DE and TCP far better than other crops, and is used as necessary when other crops face demand, production, or export limits.

The final two scenarios show impacts of changes in the world market for Pakistan's most important agricultural export crops. In Model 7, the restricted quantity of exported Irri rice is increased by one-third and production expands to fully meet this added market opportunity. In Model 8, world prices of cotton are increased by 25 percent to induce greater exports of that crop.

As Irri rice production for export expands in Model 7, cotton, the primary competitor for land, loses hectarage. Coarse grain land increases to provide additional feedstuffs, as does kharif fodder. Crop hectarage in rabi remains generally unchanged, although there are slight increases in pulses and barley and a small reduction in fodder. Model 8 demonstrates the reverse sequence, with one major exception. As cotton hectarage grows, the need for additional feedstuffs from other crops declines, so coarse grains are reduced and kharif fodder hectarage drops by five percent. Part of the coarse grain area decline in kharif shifts to rabi season, as barley hectarage nearly doubles. Cotton also requires hectarage in rabi if a fourpicking activity is chosen, so wheat and pulses areas decline to accommodate greater cotton production. The main difference between the last two scenarios is that cotton hectarage is lost when Irri rice production expands, but cotton does not displace Irri rice. The impact on rations shown in Table 6 is modest, with slight reductions in ration quality when Irri rice exports expand, but there is a more complementary relationship as cotton exports expand. Both milking and non-milking cows are fed better rations when cotton exports increase, but when rice exports grow, there is only a slight improvement for milking cows, and a reduction in ration quality for nonmilking cows.

\section{CONCLUSIONS}

The overall picture drawn in this paper has several implications for the agricultural sector in Pakistan. First, fodder hectarage will quite likely increase with the added livestock production needed to meet the greater demand as per capita income grows in Pakistan, partly because of the limited ability of livestock to consume low energy roughages because of stomach capacity limitations, but more importantly because of the need to provide green fodder that is constrained by season. This was seen most explicitly in Model 5, where seasonal constraints on the green fodder use increased the needed kharif fodder hectarage. 
The second point is that if the traditional livestock ownership structure remains, there may be a greater herd size than warranted, and excessive land, water, and fertiliser resources would be diverted to livestock maintenance. The comparison between Models 5 and 6, in which Model 6 was a proxy for a more modern system that produces more meat per cow and uses a ration with a higher proportion of concentrate, is illustrative. By maintaining fewer cows in a modern, feedlot-based sub-sector, more concentrate could be fed to the smaller herd, and land could be released for production of other crops. Cotton and wheat are the main crops that expand with this change.

The recently concluded Uruguay Round of the GATT has begun the process of agricultural trade liberalisation and will likely terminate the Multifibre Agreement in textiles. Cotton and rice exports of Pakistan should grow, with several implications for the livestock sector [Ender (1990)]. Our simulations demonstrated that exports of rice would expand in response to a growing market, even at current prices, but cotton exports would only increase if world prices strengthen. Cotton hectarage is lost when Irri rice production expands, but cotton does not displace Irri rice. There is an opposite impact on rations when exports grow for each of these crops; slight reductions in ration quality occur when Irri rice exports expand, but a more complementary relationship exists as cotton exports expand. Both milking and non-milking cows are fed somewhat higher energy rations when cotton exports increase, but when rice exports grow, there is only a slight improvement for milking cows and a reduction in ration quality for non-milking cows. Related to this change, when rice exports expand, coarse grain and kharif fodder production increases to provide additional feedstuffs. As cotton hectarage grows, the need for additional feedstuffs from other crops declines, so coarse grains hectarage declines and kharif fodder hectarage drops by five percent.

Finally, this paper has endeavoured to demonstrate the importance of livestock in the overall performance of Pakistan's agricultural sector and to indicate the usefulness of sector modelling. The explicit incorporation of livestock and crop sectors has been a unique feature of these simulations, in which extensive substitute and complementary relationships between various crops and livestock were found. The impacts of a modern livestock feeding industry and increased cotton and rice exports are just two of the analyses possible with the PASM. Further research would allow for a richer inclusion of imports and exports of feedstuffs and meat products, and a more explicit modelling of the livestock feeding industry. The opportunity to incorporate this model into an on-going process of data collection, policy analysis, and model refinement through the Economic Wing of the Government of Pakistan is unique, and should lead to improvements of data, the PASM model itself, and, with some hope, the agricultural policy analysis in Pakistan. 


\section{REFERENCES}

Adams, R. M., S. A. Hamilton, and B. A. McCarl (1986) The Benefits of Pollution Control: The Case of Ozone and US Agriculture. American Journal of Agricultural Economics 68: 886-93.

Ahmad, Manzoor, and Rajan K. Sampath (1994) Irrigation Inequalities in Pakistan 1960-1980: A District-level Analysis. The Pakistan Development Review 33:1 53-74.

Akmal, Muhammad (1993) A Dynamic Model of Milk Production Response for Pakistan. The Pakistan Development Review 32:4 873-884.

Akmal, Muhammad (1994) The Production and Consumption of Livestock Foods in Pakistan: A Look into the Future. The Pakistan Development Review 33:1 19-39.

Ali, Mubarik (1990) The Price Response of Major Crops in Pakistan: An Application of the Simultaneous Equation Model. The Pakistan Development Review 29:3\&4 305-325.

Apland, Jeffrey, and Hans Andersson (1996) Optimal Location of Processing Plants: Sector Modelling Considerations and an Example. Review of Agricultural Economics 18: 491-504.

Chang, C.-C., B. A. McCarl, J. W. Mjelde, and J. W. Richardson (1992) Sectoral Implications of Farm Programme Modifications. American Journal of Agricultural Economics 74: 38-49.

Coble, K. H., C.-C. Chang, B. A. McCarl, and B. R. Eddleman (1992) Assessing the Economic Impact of New Technology: The Case of Cornstarch-based Biodegradable Plastics. Review of Agricultural Economics 14: 31-43.

Davies, Amalia Rinaldi (1996) The Implications of GATT Uruguay Round on Pakistan's Agriculture: An Agricultural Sector Approach. Unpublished Ph.D. dissertation, Colorado State University, Fort Collins, Colorado, USA.

Davies, Stephen P., Amalia R. Davies, Mubarik Ali, and Faiz Mohammad (1991) The Pakistan Agricultural Sector Model (PASM): A Linear Programming Model. Islamabad, Pakistan. (Unpublished.)

Duloy, John H., and Roger D. Norton (1973) CHAC: A Programming Model for Mexican Agriculture. In L. Goreux and A. Manne (eds) Multi-level Planning: Case Studies in Mexico. Amsterdam: North Holland 291-337.

Duloy, John H., and Roger D. Norton (1975) Prices and Incomes in Linear Programming Models. American Journal of Agricultural Economics 57: 591600.

Ender, Gary (1990) Government Intervention in Pakistan's Agricultural Economy. Agriculture and Trade Analysis Division, ERS/USDA. (Staff Report No. 9027.)

Faruqee, Rashid, and Kevin Carey (1995) Reforming the Government's Role in Pakistan's Agriculture Sector. The Pakistan Development Review 34:3 225-262.

Hazell, Peter B. R., and Roger D. Norton (1986) Mathematical Programming for Economic Analysis in Agriculture. New York: Macmillan Publishing Company. 
National Academy of Sciences (1977) Nutrient Requirements of Poultry. (7th revised edn.) Washington, D. C.: National Academy Press.

National Academy of Sciences (1978) Nutrient Requirement of Dairy Cattle. (5th edn.) Washington, D. C.: National Academy Press.

National Academy of Sciences (1984) Nutrient Requirements of Beef Cattle. (6th edn.) Washington, D. C.: National Academy Press.

National Academy of Sciences (1985) Nutrient Requirements of Sheep. (6th edn.) Washington, D. C.: National Academy Press.

Pakistan, Government of (1988) Report of the National Commission on Agriculture. Islamabad: Ministry of Food, Agriculture, and Cooperatives.

Pakistan, Government of (1993) Report of Prime Minister's Task Force on Agriculture. Islamabad: Ministry of Finance, Revenue, and Economic Affairs.

Quddus, Muhammad Abdul (1993) Livestock Economy of Pakistan: An Agricultural Sector Model Approach. Unpublished Ph. D. dissertation, Colorado State University, Fort Collins, Colorado, USA.

Rosegrant, Mark W., and Robert E. Evenson (1993) Agricultural Productivity Growth in Pakistan and India: A Comparative Analysis. The Pakistan Development Review 32:4 433-451.

Samuelson, P. A. (1952) Spatial Price Equilibrium and Linear Programming. American Economic Review 62: 283-303.

Takayama, T., and G. Judge (1964) Spatial Equilibrium and Quadratic Programming. Journal of Farm Economics 46: 67-93.

Takayama, T., and G. Judge (1964a) Equilibrium among Spatially Separated Markets: A Reformulation. Econometrics 32: 510-524. 